\title{
Evaluation of the Antibacterial Activity of 5-(thiophen- 2-yl)-1H-tetrazole and Its Oxime Derivative against ATCC Reference Strains and Strains Isolated from the Hospital Environment of a Provincial Public Hospital in the City of Fez
}

Sara Hajib, Mohamed Hssaini, Anouar Alami, Hicham Bekkari, Najoua Benchemsi,

Salaheddine Boukhssas, Younas Aouine, and Hassane Faraj

\section{ABSTRACT}

Bacterial resistance to antibiotics and disinfectants has become a real concern. The hospital presents a favorable environment for the colonization and development of bacteria resistant to antibiotics and disinfectants. The search for new antimicrobial compounds is essential to combat this phenomenon. Tetrazole derivatives may represent a solution due to their interesting antibacterial activity. In this work, two tetrazole derivatives; thiophene-2-carbaldehyde (T2C) and 5-(thiophen-2-yl)-1Htetrazole (5TPh-1HT), were evaluated for their antibacterial activities against a set of reference strains and strains isolated from the hospital environment. The antibacterial effect was studied by the disc diffusion method and by determination of MIC and MBC. The 5-(thiophen-2-yl)1H-tetrazole (5TPh-1HT) has a broader spectrum of activity than its oxime derivative (T2C). The latter has bactericidal activity only on gramnegative Escherichia coli, Pseudomonas aeruginosa with MICs ranging from $0.62 \mathrm{mg} / \mathrm{ml}$ to $2.5 \mathrm{mg} / \mathrm{ml}$, while $5 T P h-1 \mathrm{HT}$ has a bactericidal effect on all strains with MICs ranging from $0.62 \mathrm{mg} / \mathrm{ml}$ to $1.25 \mathrm{mg} / \mathrm{ml}$. Both products have a significant inhibitory activity on the strains tested in particular E. coli H, S. aureus H, P. aeruginosa and Streptococcus spp A. It was found that these activities vary depending on the microbial strain tested and the product applied.

Keywords: Hospital environment, Resistant bacteria, Antibacterial activity, Tetrazole, MIC, MBC.
Published Online: March 26, 2021

ISSN: $2684-4478$

DOI : 10.24018/ejchem.2021.2.2.54

Sara Hajib

Engineering Laboratory of Organometallic, Molecular Materials and Environment (LIMOME), Faculty of Sciences Dhar El Mahraz, Sidi Mohammed Ben Abdellah University, Morocco.

(e-mail: hajib.sarah@gmail.com)

Mohamed Hssaini

Laboratory of Biotechnology, Environment, Food and Health, Faculty of Sciences Dhar El Mahraz, Sidi Mohammed Ben Abdellah University, Morocco.

(e-mail: Mohamed.hssaini@usmba.ac.ma) Anouar Alami*

Engineering Laboratory of Organometallic, Molecular Materials and Environment (LIMOME), Faculty of Sciences Dhar El Mahraz, Sidi Mohammed Ben Abdellah University, Morocco.

(e-mail: anouar.alami@ usmba.ac.ma)

Hicham Bekkari

Laboratory of Biotechnology, Environment, Food and Health, Faculty of Sciences Dhar El Mahraz, Sidi Mohammed Ben Abdellah University, Morocco.

(e-mail: hichambekkari@yahoo.fr)

Najoua Benchemsi

Laboratory of Functional Ecology and Environmental Engineering, Faculty of Sciences $\&$ Techniques Saiss, Sidi Mohamed Ben Abdellah University, Morocco.

(e-mail: najoua.benchemsi@usmba.ac.ma) Salaheddine Boukhssas

Engineering Laboratory of Organometallic, Molecular Materials and Environment (LIMOME), Faculty of Sciences Dhar El Mahraz, Sidi Mohammed Ben Abdellah University, Morocco.

(e-mail: salah.boukhssas @ gmail.com)

Younas Aouine

Team of Organic Chemistry and Valorization of Natural Substances (COVSN), Faculty of Sciences, Ibn Zohr University Morocco.

(e-mail: y.aouine@ uiz.ac.ma)

Hassane Faraj

Engineering Laboratory of Organometallic, Molecular Materials and Environment (LIMOME), Faculty of Sciences Dhar El Mahraz, Sidi Mohammed Ben Abdellah University, Morocco.

(e-mail: hassanefaraj ${ }^{@}$ yahoo.fr)

*Corresponding Author 


\section{INTRODUCTION}

The hospital is a place of care, but also a place where one can contract infectious diseases [1]. Contamination contracted in the hospital is at the origin of infections, known as nosocomial infections. The latter is a serious public health problem with considerable consequences both for individuals and for the economy [2]. Bacteria can be transmitted through direct contact or through the hospital environment (air, water, food, materials). Most of the bacteria responsible for nosocomial infections are multi-resistant bacteria [3]. The acquisition of bacterial resistance to antimicrobial agents, particularly antibiotics, is due to the overuse of TBAs in human medical practice, whether in hospital or community settings. The use of disinfectants with sub-inhibitory concentrations also causes bacterial resistance to a range of disinfectants [4].

Faced with this world-wide problem, which is growing considerably and constitutes a major threat to public health, it is necessary to find new antimicrobial molecules that can be the basis of new antibiotics or disinfectants. Indeed, the chemical synthesis of new antibacterial molecules is essential to combat the phenomena of bacterial resistance. In recent years, many teams of researchers have been interested in the synthesis and study of new heterocyclic compounds. Tetrazoles constitute an important class of these compounds which have received a lot of interest through their various biological activities [5]-[16] in particular antibacterial activity [17]-[21]. Tetrazoles and their derivatives also occupy an important place in the drug market [22]. Examples of drugs based on tetrazole or its derivatives include Pentetrazol, Candesartan cilexetil and Ceftezole.

Thus, in the continuation of our previous work on the evaluation of antibacterial activity of tetrazolic compounds and their precursors, synthesized in our laboratory [23]-[24], we present in this paper the results of the tests of antibacterial activity of two synthetic chemical molecules derived from tetrazole, namely thiophene-2-carbaldehyde oxime (T2C) and the 5-(thiophen-2-yl)-1H-tetrazole (5TPH-1HT) [17][18] on different types of bacterial strains: ATCC reference strains and strains isolated from the environment of the Hassan II University Hospital Center in Fez.<smiles>O/N=C/c1cccs1</smiles>

T2C<smiles>c1csc(-c2nnn[nH]2)c1</smiles>

5TPH-1HT
Fig. 1. structures of the two synthetic molecules tested.

\section{RESULTS AND DISCUSSION}

\section{A. Chemistry}

The two organic compounds tested are the 5-(thiophen-2yl)-1H-tetrazole, substituted in position 5 by an electronattracting group, and its derivative thiophen-2-carbaldehyde oxime. These two compounds are resynthesized in the laboratory according to the same protocol used by Alami [25]. The following reaction diagram summarizes the steps in this synthesis.

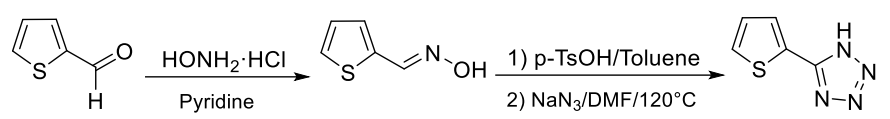

Scheme 1. Synthesis strategy of tetrazole derivative and its precursor oxime.

\section{B. Biology}

The evaluation of the antibacterial activity of the two synthesised compounds was carried out on different types of bacterial strains.

- Strains of ATCC References:

$\checkmark$ Esherichia coli ATCC 25922 (E. coli R),

$\checkmark$ Staphylococcus aureus ATCC 29213 (S. aureus R),

$\checkmark$ Bacillus subtilis ATCC 3366 (B. subtilis R), Pseudomenas aeruginosa ATCC 27853 (P. aeruginosa $\mathrm{R})$.

Strains isolated from the hospital environment (intensive care unit) of the provincial public hospital of the city of $\mathrm{Fez}$ (CHU of Fez). The strains were identified by our research team [20]:

$\checkmark$ Esherichia coli (E. coli H)

$\checkmark$ Staphylococcus aureus (S. aureus H).

- Isolated strains of Foods for Hassan II Hospital patients, purified and preserved at $-80{ }^{\circ} \mathrm{C}$ in the Laboratory of the Faculty of Medicine and Pharmacy of Fez:

$\checkmark$ Esherichia coli (E. coli A),

$\checkmark$ Staphylococcus aureus (S. aureus A),

$\checkmark$ Pseudomenas aeruginosa (P. aeruginosa A),

$\checkmark$ Streptococcus spp (Streptococcus A).

1. Evaluation of the sensitivity of bacteria to tetrazole derivatives by disk diffusion

The sensitivity of the four ATCC reference strains, as well as the six strains isolated from the hospital environment, is evaluated by the disc diffusion method.

1.1. Identification of antibacterial activity against ATCC strains

Table 1 shows the results of the diameters of the growth inhibition aureoles of ATCC strains by the tetrazole derivative and its oxime precursors (expressed in $\mathrm{mm}$ ).

TABLE I: DIAMETERS OF INHIBITION HALOS (IN MM) OF THE T2C AND 5TPH-1HT PRODUCTS AGAINST ATCC STRAINS

\begin{tabular}{cccc}
\hline \hline ATCC strains & T2C & 5TPh-1HT & Ampicilline* \\
\hline E. coli R & $9 \pm 1.4$ & $4.5 \pm 0.7$ & $23,5 \pm 1$ \\
S. aureus R & $2 \pm 0$ & $7,5 \pm 0.3$ & $21 \pm 0.7$ \\
B. subtilis R & $2 \pm 0$ & $6,5 \pm 0.3$ & $42 \pm 1.4$ \\
P. aeruginosa R & $12 \pm 2.8$ & $12,5 \pm 1.1$ & $23,5 \pm 1$ \\
\hline \hline *Positive control: Ampicillin $(100 \mu \mathrm{g} / \mathrm{ml})$.
\end{tabular}

The oxime product has an inhibitory activity on Gramnegative bacteria; E. coli $\mathrm{R}$ and $\mathrm{P}$. aeruginosa $\mathrm{R}$, with a halo diameter of inhibition of 9 and $12 \mathrm{~mm}$ respectively. It has a low inhibitory activity on Gram positive $\mathrm{S}$. aureus R and B. subtilis R (2 mm) (Table I). These results corroborate with the work of Dhayanithi et al. [31] on tetrazole derivatives containing the piperazine group. The latter show inhibitory activity on E.coli (8-10 $\mathrm{mm})$ and P.aeruginosa (7-12 $\mathrm{mm})$.

As for the tetrazolic derivative, it is highly active on $\mathrm{P}$. aeruginosa $\mathrm{R}(12.5 \mathrm{~mm})$, moderately active on $\mathrm{S}$. aureus $\mathrm{R}$ $(7.5 \mathrm{~mm})$ and $\mathrm{B}$. subtilis $\mathrm{R}(6.5 \mathrm{~mm})$, and weakly active on $\mathrm{E}$. coli R ( $4.5 \mathrm{~mm})$ (Table I). Similar results have been obtained in numerous studies, notably those carried out by Mohite et al. [26] with 5-phenyl-tetrazoles and Kategaonkar et al. [27] 
with tetrazolo [1,5-a] quinolone derivatives. These compounds caused inhibition of E. coli, S.aureus and B.subtilis strains with inhibition diameters of 5, 7 and 6-9 $\mathrm{mm}$ respectively. Benzyl-substituted tetrazole derivatives have inhibitory activity on P. aeruginosa with a $13 \mathrm{~mm}$ halo of inhibition [28]. The effects of our products on P. aeruginosa are promising compared to those obtained by Yildirir et al. [29] with phenylselanyl-1-(toluene-4-sulfonyl)-1H-tetrazole to which P. aeruginosa was resistant.

1.2. Identification of antibacterial activity against strains of hospital origin

Table II shows the results of the diameters of the inhibition aureoles of the two compounds on strains of hospital origin.

TABLE II: DIAMETERS OF INHIBITION HALOS (IN MM) OF THE T2C AND 5TPH-1HT PRODUCTS AGAINST STRAINS OF HOSPITAL ORIGIN

\begin{tabular}{cccc}
\hline $\begin{array}{c}\text { Strains of hospital } \\
\text { origin }\end{array}$ & T2C & 5TPh-1HT & Ampicilline* $^{*}$ \\
\hline E. coli A & $4.5 \pm 0.71$ & $5 \pm 0$ & $6 \pm 1.4$ \\
E. coli H & $14,5 \pm 0.71$ & $7 \pm 1.41$ & $14.5 \pm 0.71$ \\
S. aureus H & $4.5 \pm 0.71$ & $8,5 \pm 0.71$ & $25.5 \pm 1$ \\
S. aureus A & $6,5 \pm 0.71$ & $7 \pm 0$ & $26 \pm 0.71$ \\
P. aeruginosa A & $14 \pm 1.41$ & $4.5 \pm 0.71$ & $5 \pm 0$ \\
Streptococcus A & $7 \pm 0$ & $5,5 \pm 0.71$ & $11 \pm 0$ \\
\hline \hline *Positive control: Ampicillin $(100 \mu \mathrm{g} / \mathrm{ml})$ &
\end{tabular}

*Positive control: Ampicillin $(100 \mu \mathrm{g} / \mathrm{ml})$.

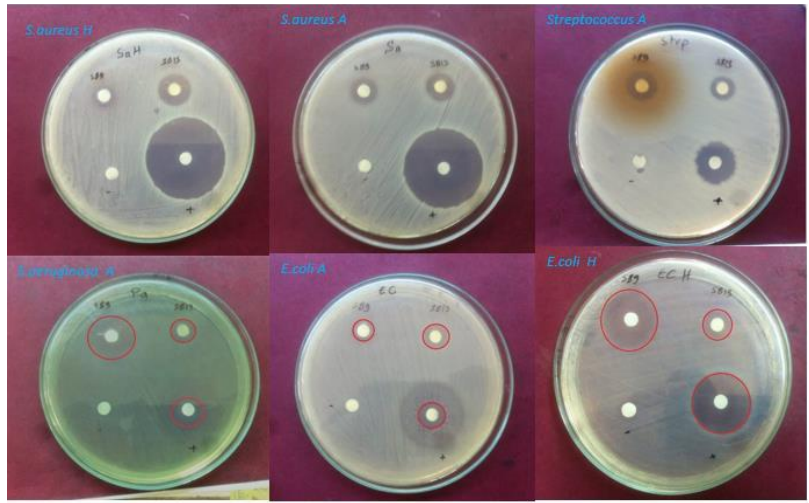

Fig. 2. Expression of activity of both Oxime and Tetrazole on bacterial strains tested. The oxime sensitivity (T2C) test of the different strains of hospital origin showed high inhibitory activity on $\mathrm{E}$. coli $\mathrm{H}$ and $\mathrm{P}$. aeruginosa $\mathrm{A}$ (14.5 and $14 \mathrm{~mm}$ respectively) and moderate activity on $\mathrm{S}$. aureus A and Streptococcus spp A (7 and $6.5 \mathrm{~mm}$ respectively). However, the bacterial strains E. coli A and S. aureus $\mathrm{H}$ were resistant $(4.5 \mathrm{~mm})$.

The 5-(thiophen-2-yl)-1H-tetrazole (5TPh-1HT) has a high inhibitory activity on $\mathrm{S}$. aureus $\mathrm{H}(8.5 \mathrm{~mm})$, and a moderate inhibitory activity on E. coli $\mathrm{H}$ and $\mathrm{S}$. aureus $\mathrm{A}(7 \mathrm{~mm})$. However, this inhibitory activity is low on E. coli A, P. aeruginosa A and Streptococcus A with 5, 4.5 and $5.5 \mathrm{~mm}$ inhibition diameters, respectively (Table II).

To our knowledge, there is not much work already done on the antimicrobial activity of tetrazole derivatives on strains of hospital origin except a study by Morjan et al. [30] on 5-oxo and 5-thiotetrazoles 1,4-disubstituted derivatives. The results of this study show that some 5-oxo-tetrazole derivatives have activities on E. coli, Streptococcus spp and S. aureus with halos of inhibition of $5 \mathrm{~mm}, 5-$ $6 \mathrm{~mm}$ and $6 \mathrm{~mm}$ respectively. These 5-oxo-tetrazole derivatives are not active on $\mathrm{P}$. aeruginosa, while other 5-thio-tetrazole derivatives are highly active on P. aeruginosa, S. aureus, E. coli, and Streptococcus spp.

All reference strains are highly sensitive to ampicillin with halos of inhibition between $23.5 \mathrm{~mm}$ and $42 \mathrm{~mm}$. On the other hand, E. coli A and P. aeruginosa A have been shown to be more resistant to ampicillin with inhibition diameters $\leq 6 \mathrm{~mm}$.
Also, the role of tetrazole ring substituents on antibacterial activity, which can modify the chemical properties of these tetrazoles (hydrophobicity...), by influencing their mode of action.

2. Determination of Minimum Inhibitory Concentrations (MICs)

Tables III-VI summarize the results of the determination of minimum inhibitory concentrations of tetrazole derivative (5TPh-1HT) and its oxime precursor (T2C) against the reference strains ATCC (E. coli R, S. aureus R, B. subtilis R and $\mathrm{P}$. aeruginosa $\mathrm{R}$ ) and strains isolated from hospital environments (E. coli A, E. coli H, S. aureus A, S. aureus H, $\mathrm{P}$. aeruginosa A and Streptococcus spp A). The MIC corresponds to the lowest concentration that has shown no visible bacterial growth.

2.1. Minimum Inhibitory Concentrations against ATCC reference strains

Tables III and IV show that both compounds have antibacterial activity on ATCC strains and confirm the qualitative test results. Indeed, the oxime derivative inhibits the growth of P. aeruginosa R strain at a MIC of $0.62 \mathrm{mg} / \mathrm{ml}$, E. coli R strain at a MIC of $1.25 \mathrm{mg} / \mathrm{ml}$ and $\mathrm{S}$. aureus $\mathrm{R}$ and B. subtilis R strains at a MIC of $2.5 \mathrm{mg} / \mathrm{ml}$ (Table III).

TABLE III: MINIMUM INHIBITORY CONCENTRATIONS (MG/ML) OF T2C ON ATCC STRAINS

\begin{tabular}{cccccccc}
\hline \hline $\begin{array}{c}\text { Concentration } \\
(\mathrm{mg} / \mathrm{ml})\end{array}$ & 2.5 & 1.25 & 0.625 & 0.31 & 0.15 & 0.07 & Témoin \\
\hline E. coli R & - & - & + & + & + & + & + \\
S. aureus R & - & + & + & + & + & + & + \\
B. subtilis R & - & + & + & + & + & + & + \\
P. aeruginosa R & - & - & - & + & + & + & + \\
\hline \hline
\end{tabular}

5TPh-1HT inhibits the growth of all ATCC strains with a $1.25 \mathrm{mg} / \mathrm{ml} \mathrm{MIC}$, except $\mathrm{P}$. aeruginosa $\mathrm{A}$, which is inhibited at a $0.62 \mathrm{mg} / \mathrm{ml}$ MIC (Table IV).

TABLE IV: MiNIMUM INHIBITORY CONCENTRATIONS (MG/ML) OF 5TPH1HT ON ATCC STRAINS

\begin{tabular}{cccccccc}
\hline \hline $\begin{array}{c}\text { Concentration } \\
(\mathrm{mg} / \mathrm{ml})\end{array}$ & 2.5 & 1.25 & 0.625 & 0.31 & 0.15 & 0.07 & Témoin \\
\hline E. coli R & - & - & + & + & + & + & + \\
S. aureus R & - & - & + & + & + & + & + \\
B. subtilis R & - & - & + & + & + & + & + \\
P. aeruginosa R & - & - & - & + & + & + & + \\
\hline \hline
\end{tabular}

In the literature, the results of the CMIs of tetrazole derivatives vary widely, ranging from $\mu \mathrm{g}$ to $\mathrm{mg}$. Indeed, the studies of Dhayanithi et al. [31] from tetrazole derivatives show that E. coli and S. aureus strains were inhibited with a $6.25 \mathrm{mg} / \mathrm{ml} \mathrm{MIC}$ and P. aeruginosa was inhibited with a 50 $\mathrm{mg} / \mathrm{ml}$ MIC. In a second study with other tetrazole derivatives, the same authors found that these products inhibited S. aureus, E. coli, and P. aeruginosa with an IMC of $12.5 \mathrm{mg} / \mathrm{ml}$ [28]. Other studies have shown that the MIC values of tetrazole derivatives on E. coli, B. subtilis, S. aureus, and $\mathrm{P}$. aeruginosa range from $10 \mu \mathrm{g} / \mathrm{ml}$ to $250 \mu \mathrm{g} / \mathrm{ml}$ [27], [32]-[33].

\subsection{Minimum Inhibitory Concentrations against strains of} hospital origin

The results of Table $\mathrm{V}$ show that thiophene 2carbaldehyde (T2C) has an inhibitory activity against the strains tested. The strains E. coli $\mathrm{H}$ and $\mathrm{P}$. aeruginosa A were found to be more sensitive $(\mathrm{CMI}=1.25 \mathrm{mg} / \mathrm{ml})$ than $\mathrm{E}$. coli A, S. aureus A, S. aureus H, and Streptococcus spp A (CMI $=2.5 \mathrm{mg} / \mathrm{ml})($ Table $\mathrm{V})$. 
TABLE V: MINIMUM INHIBITORY CONCENTRATIONS (MG/ML) OF T2C ON STRAINS OF HOSPITAL ORIGIN

\begin{tabular}{cccccccc}
\hline \hline $\begin{array}{c}\text { Concentration } \\
(\mathrm{mg} / \mathrm{ml})\end{array}$ & 2.5 & 1.25 & 0.625 & 0.31 & 0.15 & 0.07 & Témoin \\
\hline E. coli A & - & + & + & + & + & + & + \\
E. coli H & - & - & + & + & + & + & + \\
S. aureus A & - & + & + & + & + & + & + \\
S. aureus H & - & + & + & + & + & + & + \\
P. aeruginosa A & - & - & + & + & + & + & + \\
Streptococcus & - & + & + & + & + & + & + \\
spp A & - & + & & + & \\
\hline \hline
\end{tabular}

MIC values obtained with $5 \mathrm{TPh}-1 \mathrm{HT}$ indicate that this product has a greater inhibitory effect than that obtained with T2C. In fact, all strains were inhibited at a concentration of $1.25 \mathrm{mg} / \mathrm{ml}$, except E. coli strain which was found to be less sensitive to the tetrazolic derivative with a MIC of around 2.5 $\mathrm{mg} / \mathrm{ml}$ (Table VI).

TABLE VI: MINIMUM INHIBITORY CONCENTRATIONS (MG/ML) OF 5TPH1HT ON STRAINS OF HOSPITAL ORIGIN

\begin{tabular}{cccccccc}
\hline \hline $\begin{array}{c}\text { Concentration } \\
(\mathrm{mg} / \mathrm{ml})\end{array}$ & 2.5 & 1.25 & 0.625 & 0.31 & 0.15 & 0.07 & Témoin \\
\hline E. coli A & - & + & + & + & + & + & + \\
E. coli H & - & - & + & + & + & + & + \\
S. aureus A & - & - & + & + & + & + & + \\
S. aureus H & - & - & + & + & + & + & + \\
P. aeruginosa & - & - & + & + & + & + & + \\
A & & & & & & & + \\
$\begin{array}{c}\text { Streptococcus } \\
\text { spp A }\end{array}$ & - & - & + & + & + & + & + \\
\hline \hline
\end{tabular}

It should be noted that the work of Morjan et al. [30] have shown that 5-oxo and 5-thio-tetrazoles 1,4-disubstitute derivatives inhibit the growth of isolated strains in the hospital environment; S.aureus and E.coli with a MIC of 0.2 $\mathrm{mg} / \mathrm{ml}$ and $0.6 \mathrm{mg} / \mathrm{ml}$ respectively.

2.3. Comparison of the effects of tetrazole derivatives on the different strains tested

Based on the data in Tables VII and Fig. 2, both T2C and $5 \mathrm{TPh}-1 \mathrm{HT}$ products have the same MIC on Gram-negative strains (E. coli and P. aeruginosa). Tetrazole 5TPh-1HT is more active on Gram-positive strains (S. aureus, B. subtilis, and Streptococcus spp) than the oxime derivative.

TABLE VII: COMPARISON OF MICS OF T2C AND 5TPH-1HT ON THE STRAINS TESTED

\begin{tabular}{ccc}
\hline \hline Souches bactériennes & $\begin{array}{c}\text { CMI du SB } \\
(\mathrm{mg} / \mathrm{ml})\end{array}$ & $\begin{array}{c}\text { CMI du SB 13 } \\
(\mathrm{mg} / \mathrm{ml})\end{array}$ \\
\hline E. coli R & 1.25 & 1.25 \\
P. aeruginosa R & 0.62 & 0.62 \\
S. aureus R & 2.5 & 1.25 \\
B. subtilis R & 2.5 & 1.25 \\
E. coli A & 2.5 & 2.5 \\
E. coli H & 1.25 & 1.25 \\
P. aeruginosa A & 1.25 & 1.25 \\
S. aureus A & 2.5 & 1.25 \\
S. aureus H & 2.5 & 1.25 \\
Streptococcus spp A & 2.5 & 1.25 \\
\hline \hline
\end{tabular}

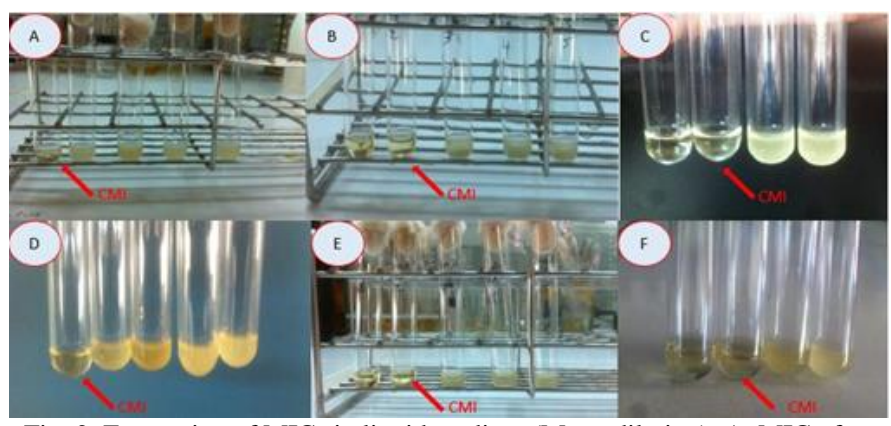

Fig. 2. Expression of MICs in liquid medium (Macrodilution): A: MIC of T2C on E. coli A, B: MIC of 5TPh-1HT on E. coli H, C: MIC of 5TPh-1HT on P. aeruginosa A, D: MIC of T2C on S. aureus A, E: MIC of 5TPh-1HT on S. aureus H, F: MIC of 5TPh-1HT on Streptocuccus spp A.

\subsection{Determination of minimum bactericidal concentrations (MBCs)}

The minimum bactericidal concentration of the two T2C and 5TPh-1HT products, which corresponds to the lowest concentration of these products with a maximum number of 5 colonies on a box, was determined. Tables VIII-IX represent the results of CMBs obtained on ATCC and hospital-derived strains.

\subsubsection{Minimum Bactericidal Concentrations (MBCs)} against ATCC reference strains

The CMB of the oxime product is $2.5 \mathrm{mg} / \mathrm{ml}$ for both $\mathrm{E}$. coli R, P. aeruginosa R. It is greater than $2.5 \mathrm{mg} / \mathrm{ml}$ for $\mathrm{S}$. aureus R and B. subtilis R (Table VIII).

TABLE VIII: MINIMUM BACTERICIDAL CONCENTRATIONS (MG/ML) OF T2C ON ATCC STRAINS

\begin{tabular}{cccc}
\hline \hline $\begin{array}{c}\text { Concentration } \\
(\mathrm{mg} / \mathrm{ml})\end{array}$ & 2,5 & 1,25 & 0,625 \\
\hline E.coli $R$ & - & + & + \\
S.aureus $R$ & + & + & + \\
B.subtilis $R$ & + & + & + \\
P.aeruginosa $R$ & - & + & + \\
\hline \hline
\end{tabular}

Table IX shows that the Minimum Bactericidal Concentration of $5 \mathrm{TPh}-1 \mathrm{HT}$ is $2.5 \mathrm{mg} / \mathrm{ml}$ for all ATTC strains.

TABLE IX: MINIMUM BACTERICIDAL CONCENTRATIONS (MG/ML) OF 5TPH-1HT ON ATCC STRAINS

\begin{tabular}{cccc}
\hline \hline $\begin{array}{c}\text { Concentration } \\
(\mathrm{mg} / \mathrm{ml})\end{array}$ & 2,5 & 1,25 & 0,625 \\
\hline E.coli $R$ & - & + & + \\
S.aureus $R$ & - & + & + \\
B.subtilis $R$ & - & + & + \\
P.aeruginosa $R$ & - & + & + \\
\hline \hline
\end{tabular}

Thus, the oxime derivative has a bactericidal effect on $\mathrm{E}$. coli $\mathrm{R}$ and $\mathrm{P}$. aeruginosa $\mathrm{R}$, while the tetrazole derivative has a bactericidal effect on all ATCC strains tested $(\mathrm{CMB} / \mathrm{CMI} \leq$ 4). It should be noted that the work of Rao et al [34] has shown that the MBCs of some tetrazole derivatives vary between 0.5 and $1 \mathrm{mg} / \mathrm{ml}$ against the strains $\mathrm{S}$. aureus and B. subtilis. Whereas the BMC against E. coli is of the order of $6.25 \mathrm{mg} / \mathrm{ml}$.

2.4.2. Minimum Bactericidal Concentrations (MBCs) against hospital strains

The MBC of T2C is $2.5 \mathrm{mg} / \mathrm{ml}$ on the P.aeruginosa A and Streptococcus spp A strain. While the other strains are resistant to the $\mathrm{T} 2 \mathrm{C}$ product, the $\mathrm{MBC}$ remains above $2.5 \mathrm{mg} / \mathrm{ml}$ (Table X). 
TABLE X: MiNIMUM BACTERICIDAL CONCENTRATIONS (MG/ML) OF T2C ON STRAINS OF HOSPITAL ORIGIN

\begin{tabular}{cccccc}
\hline \hline Concentration $(\mathrm{mg} / \mathrm{ml})$ & 2,5 & 1,25 & 0,625 & 0,31 & 0.15 \\
\hline E. coli A & + & + & + & + & + \\
E. coli H & + & + & + & + & + \\
S. aureus A & + & + & + & + & + \\
S. aureus H & + & + & + & + & + \\
P. aeruginosa A & - & + & + & + & + \\
Streptococcus spp A & - & + & + & + & + \\
\hline \hline
\end{tabular}

As for the product 5TPh-1HT, it presents an MBC of 2.5 $\mathrm{mg} / \mathrm{ml}$ on both strains of E. coli, as well as on P. aeruginosa A. The BMC of the tetrazole derivative on S. aureus A, S. aureus $\mathrm{H}$ and Streptococcus spp A is $1.25 \mathrm{mg} / \mathrm{ml}$ (Table XI).

TABLE XI: MINIMUM BACTERICIDAL CONCENTRATIONS (MG/ML) OF 5TPH-1HT ON STRAINS OF HOSPITAL ORIGIN

\begin{tabular}{cccccc}
\hline \hline Concentration $(\mathrm{mg} / \mathrm{ml})$ & 2,5 & 1,25 & 0,625 & 0,31 & 0.15 \\
\hline E. coli A & - & + & + & + & + \\
E. coli H & - & + & + & + & + \\
S. aureus A & - & - & + & + & + \\
S. aureus H & - & - & + & + & + \\
P. aeruginosa A & - & + & + & + & + \\
Streptococcus spp A & - & - & + & + & + \\
\hline \hline
\end{tabular}

In summary, the thiophene 2- carbaldehyde (T2C) compound has a bactericidal effect on $\mathrm{P}$. aeruginosa $\mathrm{A}$ and Streptococcus ssp A, whereas 5-(thiophen-2-yl)-1H-tetrazole (5TPh-1HT) has a bactericidal effect on all hospital-derived strains tested $(\mathrm{CMB} / \mathrm{CMI}) \leq 4)$.

\section{MATERIALS AND METHODS}

This study was conducted in the Biotechnology Laboratory of the Faculty of Sciences, Sidi Mohamed Ben Abdellah University-Fez. Our study focused on the evaluation of the antibacterial activity of thiophene-2-carbaldehyde (T2C) and 5-(thiophen-2-yl)-1H-tetrazole (5TPh-1HT) compounds against four ATCC reference strains (E. coli R, S.aureus R, B.subtilis R, P.aeruginosa R) and six strains isolated from the hospital environment (E.coli A, E.coli H, S.aureus H, S.aureus A, P.aeruginosa A and Streptococcus spp A). The sensitivity of these strains is evaluated by the disc diffusion method. The evaluation of the antibacterial activity of a synthetic chemical molecule is carried out in two tests:

Qualitative method: It is a test that allows the demonstration of antibacterial activity.

Quantitative method: It is a test that allows to determine the minimum inhibitory concentration (MIC) and the minimum bactericidal concentration (MBC) that can inhibit the growth of the bacteria tested.

\section{A. Diffusion Method in Solid Media: Antibiogram}

The antibiotic susceptibility test or diffusion method is one of the oldest approaches to determining the sensitivity of bacteria to antibiotics, and remains one of the most commonly used methods in medical analysis laboratories. It is recommended by the European Committee for Antibacterial Susceptibility Testing (EUCAST) [35] and the National Committee for Clinical Laboratory Standards (CLSI) [36].

\section{Principle}

This method consists of placing a disk soaked with the antibacterial agent in a petri dish previously sown by a bacterial species. The diffusion of the antibacterial agent into the agar creates a halo of growth inhibition of the bacteria around the disk. The susceptibility of bacterial strains to the products tested could be classified into three profiles according to the halo diameter of inhibition [37]:

- Highly active: inhibition zone $>12 \mathrm{~mm}$.

- Moderately active: 6-11 mm inhibition zone.

- Low active: $<5 \mathrm{~mm}$ inhibition zone.

\subsection{Experimental Protocol}

The antibacterial activity by diffusion on disks of the two tested compounds (T2C, 5TPh-1HT), was performed according to the Protocol recommended by EUCAST and CLSI, with some modifications [35]-[36].

\subsubsection{Preparation of solutions of tetrazole derivatives}

A quantity of $15 \mathrm{mg}$ of T2C or 5TPh-1HT was solubilized in $60 \mu \mathrm{l}$ of DMSO to obtain a final concentration of $250 \mathrm{mg} / \mathrm{ml}$.

\subsubsection{Inoculum preparation}

From a 24-hour pure bacterial culture on LB medium (Appendix 1), 3-4 colonies were collected with a handle and transferred to $5 \mathrm{ml}$ of LB medium to prepare a bacterial suspension. The latter has been homogenized. The turbidity of the bacterial suspension was adjusted to a $\mathrm{DO}=0.1$ at $600 \mathrm{~nm}$, equivalent to that of the McFarland 0.5 standard, which corresponds to an inoculum with a bacterial load of $108 \mathrm{CFU} / \mathrm{ml}$ [36] (Appendix 2).

\subsubsection{Inoculation of the boxes}

The inoculation was carried out by the swabbing method on boxes containing the LB medium. A sterile cotton swab was dipped into the bacterial suspension. Excess liquid was removed by turning the swab on the walls of the tube.

\subsubsection{Disc deposit}

Whatman paper discs, $\mathrm{N}^{\circ} 1,6 \mathrm{~mm}$ in diameter, previously sterilised (prepared and autoclaved for 20 minutes at $121^{\circ} \mathrm{C}$ ) were deposited on the surface of agar sown with the bacterial strains to be tested. $10 \mu 1$ solutions of SB 9 or SB 13 were deposited on the discs. $10 \mu \mathrm{l}$ of Ampicillin $(100 \mu \mathrm{g} / \mathrm{ml})$ were deposited on discs used as positive controls. The negative control was a disc containing $10 \mu \mathrm{l}$ of DMSO. The plates were incubated at $37{ }^{\circ} \mathrm{C}$ for 24 hours. Each test was carried out in two replicates. After 24 hours of incubation, the product with antibacterial activity formed an inhibition halo around the disc. Inhibition diameters were measured in ( $\mathrm{mm})$. Disc diameter is excluded.

\section{Determination of MICs and MBCs}

The action of the antibacterial agent on a bacterial strain can be characterised by its minimum inhibitory concentration (MIC) and its minimum bactericidal concentration (MBC).

\subsection{Determination of the Minimum Inhibitory} Concentration in a liquid medium

The MIC is defined according to the Antibiogram Committee of the French Microbiology Society (CA-SFM) as the lowest concentration that results in the inhibition of visible bacterial growth [35].

\subsubsection{Principle}

The determination of the MIC was carried out by preparing a series of dilutions from $1 / 2$ of the antimicrobial agent to be tested on liquid medium (microdilution or macrodilution). The MIC is the lowest concentration of the antibacterial agent present in the tube, well or canister that shows no visible bacterial growth [36]. 


\subsubsection{Experimental protocol}

\subsubsection{Preparation of stock solutions of chemicals}

An amount of $15 \mathrm{mg}$ of T2C or 5TPh-1HT product was solubilised in $0.5 \mathrm{ml}$ of LB medium to which $0.2 \mathrm{ml}$ of DMSO was added. $2.3 \mathrm{ml}$ of LB medium was added to give a final concentration of $5 \mathrm{mg} / \mathrm{ml}$. During this work, the MIC was determined by the liquid dilution method by macro and micro dilution.

\subsubsection{Method of dilution in liquid medium: Macrodilution}

The macrodilution method consists of preparing dilution series in test tubes with a final volume of $1 \mathrm{ml}$ [36]. The MIC determination of the products tested by macrodilution is performed according to the protocol recommended by CLSI [36] and Rao et al. [34], with some modifications.

$>$ Preparation of the inoculum

From a 24-hour pure bacterial culture on LB medium of the strains tested, a pre-culture of 3-4 hours was carried out by taking 3 to 4 colonies using a loop and then transferring them into $5 \mathrm{ml}$ of LB medium in order to prepare a bacterial suspension. The turbidity of the latter was adjusted to an $\mathrm{OD}=0.1$ at $600 \mathrm{~nm}$, equivalent to that of the McFarland 0.5 standard and which corresponds to an inoculum with a bacterial load of $108 \mathrm{CFU} / \mathrm{ml}$. Next, $5 \mathrm{ml}$ of the inoculum of the strains tested was prepared by adding $4.950 \mathrm{ml}$ of LB medium and $50 \mu \mathrm{l}$ of the bacterial suspension to dilute the bacterial load by 1/100, to have a final concentration of 106 $\mathrm{CFU} / \mathrm{ml}$.

$>$ Preparation of the dilution series of $\mathrm{T} 2 \mathrm{C}$ and $5 \mathrm{TPh}-$ $1 \mathrm{HT}$ products

$250 \mu$ of the LB medium were distributed in sterile test tubes. Then $500 \mu 1$ of T2C and 5TPh-1HT stock solutions were added to the first tube. After stirring, a cascade dilution series was performed by adding $250 \mu \mathrm{l}$ of the solution from the first tube to the second and so on until the last tube where $250 \mu \mathrm{l}$ was removed to have the same volume in all tubes. The concentrations obtained ranged from $2.5 \mathrm{mg} / \mathrm{ml}$ to $0.07 \mathrm{mg} / \mathrm{ml}$ for the two products tested.

$250 \mu \mathrm{l}$ of bacterial inoculum was added to the tubes containing the dilution series. The final volume in the tubes is $0.5 \mathrm{ml}$, and the bacterial load is $5 \times 10^{5} \mathrm{CFU} / \mathrm{ml}$. The final concentrations of the products tested range from $2.5 \mathrm{mg} / \mathrm{ml}$ to $0.07 \mathrm{mg} / \mathrm{ml}$ for T2C and 5TPh-1HT.

A negative control tube has been made, containing the bacterial inoculum at $5 \times 10^{5} \mathrm{CFU} / \mathrm{ml}$. All tubes were incubated at $37{ }^{\circ} \mathrm{C}$ for 24 hours.

The MIC is the tube containing the lowest concentration of the test product that showed no visible bacterial growth.

\subsubsection{Method of dilution in liquid medium: Microdilution}

The microdilution method consists of preparing dilution series in a 96-well polypropylene microplate. The MIC determination by microdilution was performed according to the protocol recommended by CLSI, Hellal et al. [38].

$>$ Preparation of the inoculum

The preparation of the inoculum was carried out as described above for the macrodilution except instead of preparing $5 \mathrm{ml}$ of the inoculum we prepared $2 \mathrm{ml}$.

$>$ Preparation of the dilution series of $\mathrm{T} 2 \mathrm{C}$ and $5 \mathrm{TPh}-$ 1 HT products
$100 \mu \mathrm{l}$ of LB medium were distributed in all wells except those in the first line. Then $200 \mu$ of the stock solutions of the tested products were added to the first line. The dilution series was carried out by taking $100 \mu \mathrm{l}$ from the first well in the first column and adding it to the second well belonging to the same column, and so on until the penultimate well. The same steps were repeated for the other columns. The wells were inoculated with $100 \mu$ of the bacterial suspension at a concentration of $10^{6} \mathrm{CFU} / \mathrm{ml}$. The wells in the last row of the microplate contain only the inoculum (control). The microplate was incubated at $37{ }^{\circ} \mathrm{C}$ for 24 hours. The MIC corresponds to the well, containing the lowest concentration of the test product, which showed no visible bacterial growth.

\subsubsection{Determination of the Minimum Bactericidal} Concentration $(M B C)$ in solid media

The MBC is the lowest concentration of the tested product capable of killing $99.9 \%$ of the bacteria and allowing only $0.01 \%$ to grow [39].

$>$ Protocol

From the tubes and wells used for the MIC determination, $5 \mu \mathrm{l}$ of each tube or well was deposited on LB medium, then streaked and incubated at $37{ }^{\circ} \mathrm{C}$ for 24 hours. The BMC was considered to be the lowest concentration of test material that showed no growth [38].

The calculation of the BMC/MIC ratio is used to assess whether an antibacterial agent has a bactericidal $(\mathrm{BMC} / \mathrm{CMI} \leq$ 4) or bacteriostatic (BMC/MIC >4) effect [40], [41].

3. Data analysis and processing

The calculation of averages and standard deviations was developed using the Excel program.

\section{Annexes}

\subsection{Appendix 1}

Composition of the environment Luria-Bertani (LB)

$>$ Liquid LB medium

\begin{tabular}{cc}
\hline Peptone & $10 \mathrm{~g}$ \\
Yeast extract & $5 \mathrm{~g}$ \\
$\mathrm{NaCl}$ & $10 \mathrm{~g}$ \\
Distilled water & $1000 \mathrm{ml}$ \\
\hline
\end{tabular}

$>$ Solid LB Medium

\begin{tabular}{cc}
\hline Peptone & $10 \mathrm{~g}$ \\
Yeast extract & $5 \mathrm{~g}$ \\
$\mathrm{NaCl}$ & $10 \mathrm{~g}$ \\
$\mathrm{Agar}$ & 15 \\
Distilled water & $1000 \mathrm{ml}$ \\
\hline
\end{tabular}

\subsection{Appendix 2}

Protocol for the preparation of the McFarland 0.5 standard The McFarland 0.5 standard is prepared by adding a $0.048 \mathrm{~mol} / 1 \mathrm{BaCl}_{2}$ solution and $0.18 \mathrm{~mol} / 1 \mathrm{H}_{2} \mathrm{SO}_{4}$.

Preparation of a $0.048 \mathrm{~mol} / 1 \mathrm{BaCl}_{2}$ solution $(1.175 \% \mathrm{w} / \mathrm{v}$ $\mathrm{BaCl}_{2}$. ${ }_{2 \mathrm{H}} \mathrm{O}$ ): $10 \mathrm{ml} \mathrm{BaCl}_{2}$ and $0.1175 \mathrm{~g} \mathrm{BaCl}_{2} .2 \mathrm{H}_{2} \mathrm{O}$ are solubilised in $10 \mathrm{ml}$ distilled water.

Preparation of a solution of $100 \mathrm{ml}$ of $\mathrm{H}_{2} \mathrm{SO}_{4} 0.18 \mathrm{~mol} / \mathrm{l}$ $(1 \% \mathrm{v} / \mathrm{v})$ in $100 \mathrm{ml}$ of distilled water.

Preparation of McFarland 0.5

Add $0.5 \mathrm{ml}$ of the $\mathrm{BaCl}_{2}$ solution to $99.5 \mathrm{ml}$ of a $0.18 \mathrm{~mol} / \mathrm{l}$ $\mathrm{H}_{2} \mathrm{SO}_{4}$ solution and shake vigorously.

The optical density of the resulting solution should be between 0.08 and 0.13 at $625 \mathrm{~nm}$. 


\section{CONCLUSION}

Thiophene 2-carbaldehyde (T2C) and 5-(thiophen-2-yl)1H-tetrazole (5TPh-1HT) were evaluated for their antibacterial activities against a set of reference strains and strains isolated from the hospital environment. Minimum inhibitory concentrations were determined by two methods: the method of macrodilution and microdilution in liquid medium.

The oxime T2C product was more active on E. coli $\mathrm{R}$ (9 mm), P. aeruginosa R (12 mm) and E. coli H (14.5 mm). This product exhibited strong inhibitory activity on P.aeruginosa A with a $14 \mathrm{~mm}$ halo of inhibition that is greater than that obtained by ampicillin $(5 \mathrm{~mm})$. This product inhibits all strains with an MIC ranging from $1.25 \mathrm{mg} / \mathrm{ml}$ to $2.5 \mathrm{mg} / \mathrm{ml}$ with the exception of $\mathrm{P}$. aeruginosa $\mathrm{R}(\mathrm{MIC}=0.62 \mathrm{mg} / \mathrm{ml})$. The tetrazole 5TPh-1HT derivative is more active on $\mathrm{P}$. aeruginosa $\mathrm{R}(12.5 \mathrm{~mm})$ and $\mathrm{S}$. aureus $\mathrm{H}(8.5 \mathrm{~mm})$. CMI values show that 5-(thiophen-2-yl)-1H-tetrazole is more active than 2-carbaldehyde thiophene. The tetrazoolic derivative inhibits all strains with an MIC of $1.25 \mathrm{mg} / \mathrm{ml}$, with the exception of $\mathrm{P}$. aeruginosa $\mathrm{R}(\mathrm{MIC}=0.62 \mathrm{mg} / \mathrm{ml})$ and $\mathrm{E}$. coli $\mathrm{A}(\mathrm{MIC}=2.5 \mathrm{mg} / \mathrm{ml})$.

$\mathrm{CMB}$ results from the products tested showed that $\mathrm{T} 2 \mathrm{C}$ has a bactericidal effect against E. coli R, both P. aeruginosa and Streptococcus spp A. While 5TPh-1HT has a bactericidal effect on all strains tested. It can be concluded that both products have an interesting activity on hospital-derived strains, in particular E. coli H, S. aureus H, Streptococcus spp A and P. aeruginosa A.

This work constitutes an approach in the design of tetrazole derivatives compounds that can be used as an alternative to antibiotics and disinfectants. it would therefore be interesting to study the effect of the combination.

\section{ACKNOWLEDGMENT}

This work was supported by Sidi Mohammed Ben Abdellah University (USMBA) and National Center for Scientific and Technical Research (CNRST).

\section{REFERENCES}

[1] Diakaria, G. Etude de la prévalence des infections nosocomiales d'origine bactérienne dans le service de néphrologie et dans l'unitéd'hémodialyse à l'Hôpital du Point G, Faculté de Médecine de Pharmacie et D'Odonto- Stomatologie, 2002.

[2] El Rhazi, K., Elfakir, S., Berraho, M., Tachfouti, N., Serhier, Z., Kanjaa, C., Nejjari, C. Prévalence et facteurs de risque des infections nosocomiales au CHU Hassan II de Fès (Maroc). La Revue de Santé de la Méditerranée Orientale, 2007, 13 (1), 56-63. https://doi.org/10.48408/IMIST.PRSM/mm-v30i1.1149.

[3] Bekkari, H., Touijer, H., Berrada, S., Ettaybi, M., Benchemsi, N., Maniar, S. and El Ouali Lalami, A. Surveillance of bacteriological quality and resistance to desinfectants and antibiotics in a provincial hospital in Morocco. J. Mater. Environ. Sci, 2016, 7, 1, 1-8.

[4] Joly, B., Freney, J. La résistance des bactéries aux antiseptiques et désinfectants. Hygiènes, 1996, 15: 39-46.

[5] Matysiak, J., Niewiadomy, A., Krajewska-Kułak, E. Synthesis of some 1-(2,4- dihydroxythiobenzoyl)imidazoles, -imidazolines and tetrazoles and their potent activity against Candida species. Il Farmaco, 2002, 58 (6), 455-461. https://doi.org/10.1016/S0014-827X(03)000466.

[6] Chang, C.S., Lin, Y.T., Shih, S.R., Lee, C.C., Lee, Y.C., Tai, C.L., Tseng, S.N., Chern, J.H. Design, Synthesis, and Antipicornavirus Activity of 1-[5-(4 Arylphenoxy) alkyl]-3-pyridin-4- ylimidazolidin-2- one Derivatives. Journal of Medicinal Chemistry, 2005, 48 (10), 35223535. https://doi.org/10.1021/jm050033v

[7] Walker, M. A., Johnson, T., Ma, Z., Banville, J., Remillard, R., Kim, O., Zhang, Y., Staab, A., Wong, H., Torri, A., Samanta, H., Lin, Z., Deminie, C., Terry, B., Krystal, M., Meanwell N. Triketoacid inhibitors of HIV-integrase: A new chemotype useful for probing the integrase pharmacophore. Bioorganic \& Medicinal Chemistry Letters, 2006, 16, 11, 2920-2924. https://doi:10.1016/j.bmcl.2006.08.075.

[8] Bhaskar, V.H., Mohite, P.B. Synthesis, characterization and evaluation of anticancer activity of some tetrazole derivatives. Journal of Optoelectronics and Biomedical Materials, 2010, 2(4), 249 - 259.

[9] Zhang, J.Y., Wang, S., Ba, Y.Y., Xu, Z. Tetrazole hybrids with potential anticancer activity. Eur. J. Med. Chem. 2019, 178, 341 https://doi.org/10.1016/j.ejmech.2019.05.071

[10] Wang, S.Q., Wang, Y.F., Xu, Z. Tetrazole hybrids and their antifungal activities. Eur. J. Med. Chem. 2019, 170, 225. https://doi.org/10.1016/j.ejmech.2019.03.023.

[11] Roh, J., Karabanovich, G., Vlčková, H., Carazo, A., Němeček, J., Sychra, P., Valášková, L., Pavliš, O., Stolaříková, J., Klimešová, V., Vávrová, K., Pávek, P., Hrabálek, A. Development of water-soluble 3,5-dinitrophenyl tetrazole and oxadiazole antitubercular agents. Bioorg. Med. Chem. 2017, 25(20), 5468. https://doi.org/10.1016/j.bmc.2017.08.010.

[12] Gao, C., Chang, L., Xu, Z., Yan, X.F., Ding, C., Zhao, F., Wu, X., Feng, L.S. Recent advances of tetrazole derivatives as potential antitubercular and anti-malarial agents. Eur. J. Med. Chem. 2019, 163, 404. https://doi.org/10.1016/j.ejmech.2018.12.001

[13] Zhan, P., Li, Z., Liu, X., Clercq, E.D. Sulfanyltriazole/tetrazoles: A Promising Class of HIV-1 NNRTIs. Mini Rev. Med. Chem. 2009, 9(8), 1014. https://doi.org/10.2174/138955709788681618.

[14] Niranjan, K., Nitin, K., Anoop, K., Umesh, K.S. Tetrazoles: Synthesis and Biological Activity. Immun., Endoc. \& Metab. Agents in Med. Chem, 2018, 18, 1-19. hptts://doi.org/10.2174/1871522218666180525100850.

[15] Labib, M.B., Fayez, A.M., EL-Nahass, E.S., Awadallah, M., Halim, P.A. Novel tetrazole-based selective COX-2 inhibitors: Design, synthesis, anti-inflammatory activity, evaluation of PGE2, TNF- $\alpha$, IL6 and histopathological study. Bioorganic Chemistry, 2020, 104308 hptts://doi.org/10.1016/j.bioorg.2020.104308.

[16] Dhiman, N., Kaur, K., Jaitak, V. Tetrazoles as Anticancer Agents: A Review on Synthetic Strategies, Mechanism of Action and SAR Studies. Bioorganic \& Medicinal Chemistry, 2020, 28,115599. hptts://doi.org/10.1016/j.bmc.2020.115599.

[17] Ahmadi, A., Sedaghat, T., Motamedi, H., Azadi, R. Anchoring of $\mathrm{Cu}$ (II)-Schiff base complex on magnetic mesoporous silica nanoparticles: catalytic efficacy in one-pot synthesis of 5-substituted-1H-tetrazoles, antibacterial activity evaluation and immobilization of $\alpha$-amylase. Applied Organometallic Chemistry, 2020, 34. hptts://doi.org/10.1002/aoc.5572.

[18] Gao, F., Xiao, J., Huang, G. Current scenario of tetrazole hybrids for antibacterial activity. European Journal of Medicinal Chemistry, 2019, 184, 111744. hptts://doi.org/10.1016/j.ejmech.2019.111744.

[19] Salahuddin, M., Singh, S., Shantakumar, S.M. Synthesis of Some Novel Benzo Thieno [2, 3-d] pyrimidines. Rasayan journal of chemistry, 2009, 2 (1):167-173

[20] Mosaad, M., el domany, R., abd el hameed, R. Synthesis of certain pyrrole derivatives as antimicrobial agents. Acta Pharm, 2009, 59, 145-158. https://doi.org/10.2478/v10007-009-0016-9.

[21] Mohite, P.B., Bhaskar, V.H. Potential Pharmacological Activities of Tetrazoles in The New Millennium. International Journal of PharmTech Research, 2011, 3 (3), 1557-1566. http://www.sphinxsai.com/Vol.3No.3/pharm/pdf/PT=51(15571566)JS11.pdf.

[22] Kleemann, A., Engel, J. In 'Pharmaceutical Substances: Syntheses, Patents, Applications', Eds. Thieme, Stutggart. http://vlib.kmu.ac.ir/kmu/handle/kmu/67899.

[23] Dioukhane, K., Touijer, H., Alami, A., Bekkari, H., Benchemsi, N. Study of the antibacterialeffect of 5-(4-chlorophenyl)-1H-tetrazole and its oxime precurs oragainststrainsisolated from the hospitalenvironment. Journal of Medicinal and Chemical Sciences, 2018, 1(1), 18-22. hptts://doi.org/10.26655/jmchemsci.2018.6.5.

[24] Dioukhane, K. Moussaid, S., Achamlale, S., Alami, A., Kabbour, M.R., Aouine, Y., Faraj, H., Bouksaim, M., Gaye, M.L., Comparative study of antibacterial activity of some biheterocyclic "triazolic-tetrazolic" aaminoacid derivatives against strains. Moroccan Journal of Heterocyclic Chemistry, 2020, 19(2), 87-91. https://doi.org/10.48369/IMIST.PRSM/jmch-v19i2.23360.

[25] Alami, A., El Hallaoui, A., El Achqar, A., Roumestant, M. L., Viallefont, Ph. The use of 5-substituted tetrazoles in a Synthesis of 
heterocyclic $\alpha$-amino esters. Bull. Soc. Chim. Belg., 1996, 105 (12), 769.

[26] Mohite, P.B., Pandhare, R.B., Khanages, G., Bhaskar, V.H. Synthetis and in vitro antimicrobial activity of some novel chalcones containing 5-phenyltetrazole. acta Pharmaceutica Sciencia, 2010, 52, 505-510.

[27] Kategaonkar, A.H., Pokalwar, R.U., Sonar, S.S., Gawali, V.U., Shingate, B.B., Shingare, M.S. Synthesis, in vitro antibacterial and antifungal evaluations of new $\alpha$-hydroxyphosphonate and new $\alpha$ acetoxyphosphonate derivatives of tetrazolo [1, 5-a] quinoline. European Journal of Medicinal Chemistry, 2010, 45, 1128-1132. https://doi.org/10.1016/j.ejmech.2009.12.013.

[28] Dhayanithi, V., Shafisayed, S., Kumaran, K., Sankar, K.J., Ragavan, R. V., Goud, K.P. S., Kumari, N.S., Pati, H.N. Synthesis of selected 5thio-substituted tetrazole derivatives and evaluation of their antibacterial and antifungal activities. J. Serb. Chem. Soc, 2011, 76 (2), 165-175. https://doi.org/10.2298/JSC090421001D.

[29] Yildirir, Y., Faruk, M.U., Naki, C., Ozkan, H., Yavuz, S., Disli, A., Ozturk, S., Turke, L. The synthesis and investigation of the antimicrobial activity of some new phenylselanyl-1-(toluene-4sulfonyl)-1H-tetrazole derivatives. Med Chem Res, 2009, 18, 91-97. https://doi.org/10.1007/s00044-008-9110-7.

[30] Morjan, R.Y., El-Attar, N.H., Abu-Teimb, O.S., Ulrich, M., Awadallaha, A.M., Mkadmh, A.M., Elmanama, A.A., Raftery, J., AbuAwwad, F.M., Yaseen, Z. J., Elqidrea, A.F., Gardiner, J.M. Synthesis, antibacterial and QSAR evaluation of 5-oxo and 5-thio derivatives of 1, 4-disubstituted tétrazoles. Bioorganic \& Medicinal Chemistry $\begin{array}{llll}\text { Letters, } & 2015, & 25, & 4024-4028 .\end{array}$ https://doi.org/10.1016/j.bmcl.2015.04.070.

[31] Dhayanithi, V., Shafisayed, S., Ramasamy, V.R, Kumaran, K., Sankar, J., Raguraman, K. G., Nalilu, S.K., Pati, H.N. Synthesis and evaluation of a series of 1-substituted tétrazole derivatives as antimicrobial agents. Org. Commun, 2010, 3 (3), 45-56.

[32] Rostom, S.A.F., Ashour, H.M.A., Abd El Razik, H.A., Abd El Fattah, A.H.F, El-Din, N.N. Azole antimicrobial pharmacophore-based tetrazoles: Synthesis and biological evaluation as potential antimicrobial and anticonvulsant agents. Bioorganic \& Medicinal

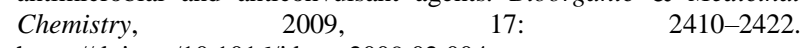
https://doi.org/10.1016/j.bmc.2009.02.004.

[33] Ramiz, M.M., Abdel-Rahman, A.A.H. Antimicrobial activity of newly synthesized 2,5-disubstiteted 1,3,4-thiodiazole derivatives. Bull. Korean Chem. Soc, 2011, 32, 4227-42320. http://dx.doi.org/10.5012/bkcs.2011.32.12.4227.

[34] Rao, S.N., Raviskankar, T., Latha, J. and SudhakarBabu, K. Synthesis, characterization and antimicrobial activity of novel biphenyl tétrazoles. Der Pharma Chemico, 2012, 4 (3), 1093-1103.

[35] EUCAST, EUropean Committee on Antimicrobial suscuptibility Testing, 2015. Comité de l'antibiogramme de la Société Française de Microbiologie, recommandations; V1.0 Janvier 2015.

[36] CLSI, Clinical and Laboratory Standards Institute, 2012. Methods for dilution antimicrobial susceptibility tests for bacteria that grow aerobically; approved standard-ninth edition. 32 (2): M02-A9.

[37] Demirbas, N., Karaoglu, S.A., Demirbas, A., Sancak, K. Synthesis and antimicrobial activities of some new 1-(5-phenylamino$[1,3,4]$ thiadiazol-2-yl)methyl-5- oxo-[1,2,4]triazoles and 1-(4-phenyl5-thioxo-[1,2,4]triazol-3-yl)methyl-5-oxo- $[1,2,4]$ triazoles derivatives. European Journal of Medicinal Chemistry, 2010, 39, 793-804. https://doi.org/10.1016/j.ejmech.2004.06.007.

[38] Hellal, A., Chafaa, S., Chafai, N. Synthesis, antimicrobial and antifungal screening of three new of Alpha-aminophosphoric acids. International Journal of Scientific and Engineering Research, 2015, 6 (8), 2229-5518.

[39] Delarras, C., Microbiologie, 90 heures de travaux pratiques. G. Morin Europe, Levallois-Perret, ISBN: 2-910749-07-X, 1998, 169-178.

[40] Berche P., Gaillard J.L., Simonet M. In Nosocomial Infections Caused by bactearia and Their Prevention in bacteriology. 1988; Edited by Flammation Medecine Sciences; 64-71.

[41] Gatsing D., Tchakoute V., Ngamga D., Kuiate J.K., Tamokou J.D.D. In vitro antibacterial activity of crinum purpurascens herb. Leaf extract against the Salmonella species causing typhoid fever and its toxicology evaluation; Iran. J. Med. Sci.; 2009, 34: 126-137.

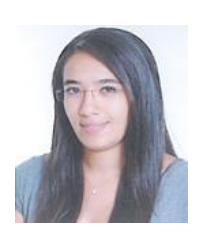

Sara Hajib was born in February 1990 in Fez, Morocco, where she completed her primary, secondary and university education.

The latter were capped respectively by obtaining a Bachelor's in chemical analysis techniques and quality control and a Master's degree in the chemistry of bioactive molecules at the Faculty of Sciences and Technologies of Fez in 2015

Currently, she is pursuing for her Ph.D. degree at Sidi Mohammed Ben Abdellah University Faculty of Sciences Dhar El Mahraz, Fez, Morocco.

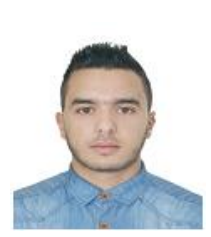

Mohamed Hssaini was born in Kaf El Ghar of Taza, Morocco, in 1995. He received his Bachelor of Science degree in biology from the University of Sidi Mohammed Ben Abdellah (USMBA) of Fez, Morocco, in 2016. He obtained his Master's degree of Science in Microbial Biotechnology from the same university, in 2018. Since 2018, he began his doctoral studies at the biotechnology laboratory of the FSDM of Fez. He won the Excellence Research Grant given by The National Center for Scientific and Technical Research (CNRST), in 2019. His research studies focuses on the field of medical genetics, especially, on sexual development diseases characterizing the Moroccan population. The main purpose of his conducted research is to identify molecular as well as functional causes of the sexual development diseases. Mohamed is currently continuing with perseverance their $\mathrm{PhD}$ studies, and plans to make the best-structured effort to success, graduate and develop more skills in the field of Genetics. In order to improve their academic backgrounds, he became member of the American society of Human Genetics (ASHG).

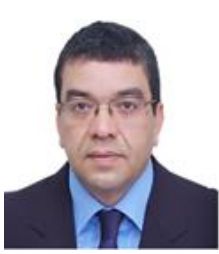

Anouar Alami was born in Fez, Morocco, in 1966. He studied Chemistry at Montpellier II University, France and he obtained his Ph.D. degree in 1991. He then joined the Department of Chemistry at the FSDM, USMBA Fez, Morocco in 1992. He prepared his state doctorate thesis degree in Organic Chemistry in 1997 at USMBA. Among the responsibilities he assumed: Head of Department of Chemistry, elected for two terms 2013-2015 and 2016-2017 of the Council of FSDM, Chairman of the TRANSMEDITERRANEAN COLLOQUIUM ON HETEROCYCLIC CHEMISTRY, November 2225, 2017, Fez, Morocco, http://tramech9.raidghost.com/, Responsible for the doctoral training "Bioactive Molecules, Health and Biotechnologies", 2014-2018, Director of the Laboratory of organic chemistry, 2014-2018, Coordinator of the Bachelor's degree program "Chemistry Sciences", FSDM, 2005-2012, Project Manager "President of the Coordination Commission with higher education, from the Board of the Academy of Fez-Boulemane Region, 2009-2012, Elected Member of the Council of USMBA, Fez, 2009-2011, Elected member of the Management Board USMBA, Fez 2011, Chairman of the International Symposium on

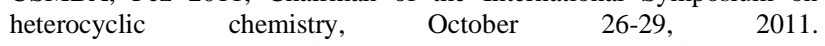
http://ishc2011.6te.net/Sitefr/index.html, Elected member of the college of the chemistry department, 2000-2012.

He strongly believes in the cognitive complementarity of science and in parallel to all his responsibilities, he had prepared a DEUG (2008) and a License (2010) in Private Law in French and a Master in Economics and Management (2013) at the Faculty of Economics, Law, and Social Sciences of Fez. Concerning the scientific research side. He had published more than 130 research articles indexed in several databases (Scopus, Web of science, Elsevier, Eric, IMIST...), in various fields: Heterocyclic chemistry, molecular biology, science education, applied research in pedagogy, Educational Technology).

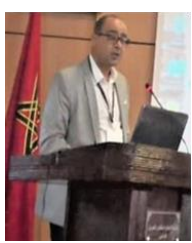

Dr. Hicham BEKKARI is a Professor of Genetics and Molecular Biology at the Dhar El Mahraz Faculty of Sciences, Sidi Mohammed Ben Abdellah University. Ph.D. in Molecular and Cellular Biology, Henri Poincaré University, Nancy France. He did his research in the Biochemistry Laboratory of the Nancy School of Medicine, the National Institute of Health and Medical Research (INSERM-Nancy) and the Biotechnology Laboratory at the Faculty of Sciences Fez. Professor H. BEKKARI is a member of the VAHVISTUS/H2020-MSCA-RISE project, co-founder of the Bioenergy and Environment Biodiversity Consortium: BBE RESEARCH GROUP. He is a member of the DAAD 
(German Academic Exchange Service) cooperation project for the development of a joint bachelor's degree between Faculty of SciencesFes/Applied Sciences University Rheinbach-Bonn. He was a member of the monitoring committee of Biotechnology's competency. He supervised many doctoral thesis work, author and co-author of several reviewed publications. He organized national and international symposia, trainings, workshops and conferences.

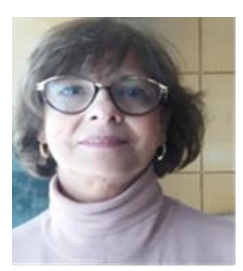

Dr. Najoua Benchemsi is a Professor of Biochemistry at the Faculty of Sciences and Technology, Sidi Mohamed Ben Abdellah University of Fez. PhD from Henri Poincaré University in Nancy, Biochemistry/Enzymology. She has done her research in the Laboratory of Biochemistry and Plant Biology of the Faculty of Science in Nancy I and in the Laboratory of Functional Ecology and Engineering of the Environment at the Faculty of Sciences and Technology of Fez. Professor Najoua BENCHEMSI is a member of many scientific research projects. She is the research director of doctoral thesis works, author and co-author of several publications of articles in national and international specialized scientific journals. Professor N. BENCHEMSI is the coordinator of the agri- food industry, engineer cycle, at FST fès. Ms. BENCHEMSI is an active member of the Women's Association for the Protection of the Environment and The Child (AHLI)

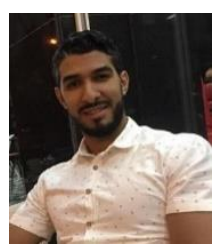

Salaheddine Boukhssas was born in Fez, Morocco, in 1992. He received his higher education degree in Chemistry and a Master's Degree in Organic Chemistry from Sidi Mohamed Ben Abdellah University, Faculty of Sciences DM of Fez, Morocco, respectively in 2014 and 2016. Then, he started a Ph.D. degree in the field of heterocyclic chemistry in the organic chemistry laboratory and he began his career as an assistant teacher in the same Faculty. In 2019, He has engaged in the field of education as a professor of Physical Sciences and Chemistry at Jbabra High school in Taounate City, Morocco.

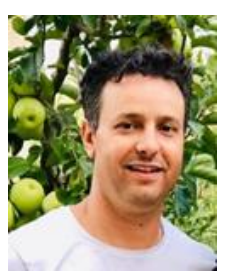

Younas Aouine was born in Ait-Seghrouchen of Taza, Morocco, in 1979. He received his higher education diploma in Chemistry from the Sidi Mohamed Ben Abdellah University of Fez, Morocco, in 2003. He obtained his advanced degree (D.E.S.A) and Ph.D. degree in Organic and Heterocyclic Chemistry from the same university, in 2005 and 2015, respectively.

Since 2006, he has been working as a researcher in organic chemistry laboratory (LCO) with Professors at Faculty of Sciences DM, University of Fez. In 2008, he joined the Ministry of Education as a professor of Physical Sciences and Chemistry in Imzouren High School, Al Hoceima in northern Morocco.

Since 2018, he joined the Department of Chemistry of the Ibn Zohr University, Agadir, as an assistant professor. His teaching has been devoted to organic and heterocyclic chemistry courses. His current research is focalized firstly on synthesis and characterization of new heterocyclic $\alpha$ amino acids and their precursors and on the other hand on the study of their biological and electrochemical activities. He has published the results of research $(+70$ publications and communications) in several international journals.

Scopus Author ID: 35742904200.

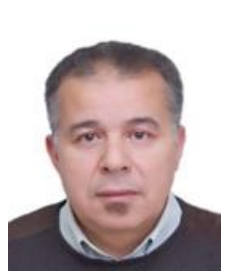

Faraj Hassane was born in Fez, Morocco, in 1963. He studied Chemistry at Montpellier II University, France and he obtained his Ph.D. degree in 1991. He then joined the department of chemistry at the Faculty of Sciences Dhar El Marhaz, Sidi Mohamed Ben Abdellah University (Fez, Morocco) in 1993.

His current research is focused on the synthesis and characterization of new heterocyclic $\alpha$-amino acids and their precursors and on the other hand on the study of their biological and electrochemical activities. He has taken part in conferences and communications in national and international congresses and has published the results of research $(+70$ publications and communications) in several international journals. 